\title{
Chapter 2 \\ Economics of Arms Trade: What Do We Know?
}

\author{
Jan van Lieshout and Robert Beeres
}

\section{Contents}

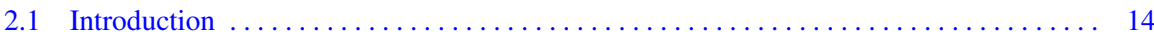

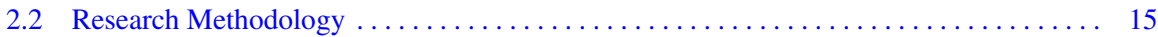

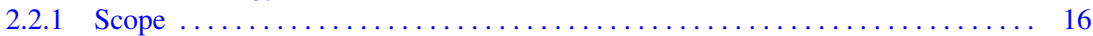

2.2 .2 Selection $\ldots \ldots \ldots \ldots \ldots \ldots \ldots \ldots \ldots \ldots \ldots \ldots \ldots \ldots \ldots \ldots \ldots \ldots \ldots \ldots$

2.2 .3 Research Synthesis $\ldots \ldots \ldots \ldots \ldots \ldots \ldots \ldots \ldots \ldots \ldots \ldots \ldots \ldots \ldots$

2.3 Weapons of Mass Destruction $\ldots \ldots \ldots \ldots \ldots \ldots \ldots \ldots \ldots \ldots \ldots \ldots \ldots \ldots \ldots \ldots$

2.3.1 Spreading Temptation: Proliferation and Peaceful Nuclear Cooperation

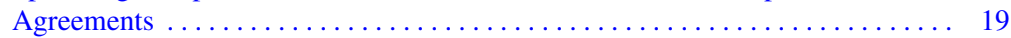

2.3.2 Almost Nuclear: Introducing the Nuclear Latency Dataset . . . . . . . . . . 20

2.3.3 Research on Weapons of Mass Destruction: What Do We Know? . . . . . . . 20

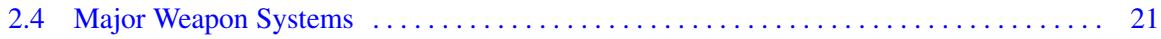

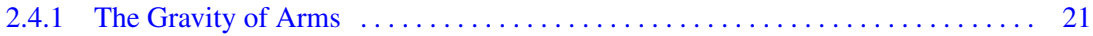

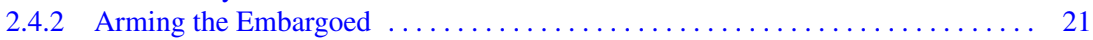

2.4.3 Arms Production, National Defence Spending and Arms Trade . . . . . . . . 22

2.4.4 Trading Arms and the Demand for Military Expenditure $\ldots \ldots \ldots \ldots \ldots \ldots 22$

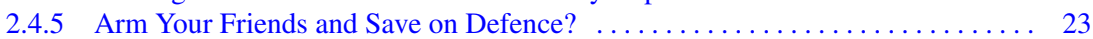

2.4.6 Network Interdependencies and the Evolution of the International Arms

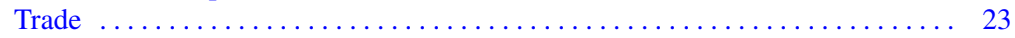

2.4.7 Research into Major Weapon Systems: What Do We Know? . . . . . . . . . . 24

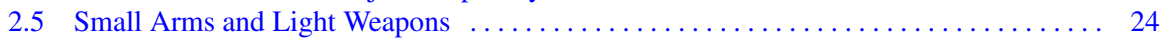

2.5.1 Weaponomics, the Economics of Small Arms $\ldots \ldots \ldots \ldots \ldots \ldots \ldots \ldots \ldots 24$

2.5.2 Research into Small Arms and Light Weapons: What Do We Know? . . . . . 25

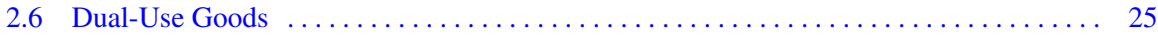

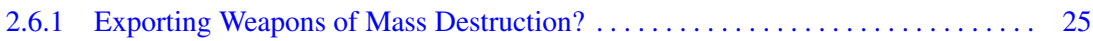

2.6.2 Taking a Walk on the Supply Side: The Determinants of Civil Nuclear

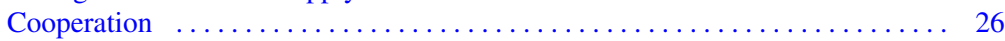

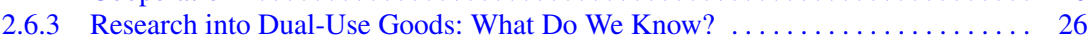

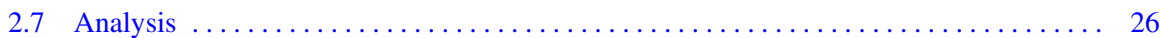

2.8 Conclusion: An Agenda for Research $\ldots \ldots \ldots \ldots \ldots \ldots \ldots \ldots \ldots \ldots \ldots \ldots \ldots \ldots$

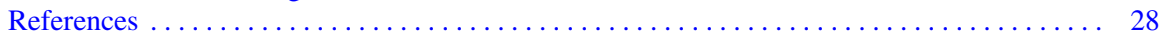

J. van Lieshout $(\varangle) \cdot$ R. Beeres

Faculty of Military Sciences, Netherlands Defence Academy, PO Box 90002, 4800 PA Breda, The Netherlands

e-mail: jmml.v.lieshout@mindef.nl

R. Beeres

e-mail: rjm.beeres@mindef.nl 


\begin{abstract}
Taking an economic perspective, and underpinned by a literature review, this chapter analyses the development of explicit sets of relationships between dependent and independent variables in the international arms trade from 1995 onwards. We distinguish five main categories within the markets of military and dual-use goods and services, comprising weapons of mass destruction, major weapon systems, small arms and light weapons, dual-use goods, and services. Per category, papers are ordered by research type and methodology. Based on our findings thus far, the final section of the chapter offers a research agenda for further studies.
\end{abstract}

Keywords Arms trade - weapons of mass destruction - major weapon systems • small arms and light weapons $\cdot$ dual-use goods and services $\cdot$ arms export control

\title{
2.1 Introduction
}

Over the years, either openly or covertly, weapons have been traded across borders, despite multiple domestic and international regulations aiming to control, forbid, prohibit or protect such arms commerce. ${ }^{1}$ During the Cold War, arms trade and transfers were mainly considered and commented on from an ideological point of view. $^{2}$ After the fall of the Berlin Wall economic drivers gained importance in conferring meaning to the motives and consequences underlying arms transfers. From then on, access to foreign markets has been regarded essential for a thriving domestic arms industry in the long run.

In 1995, conducting a review on the relations between economic motives and arms trade, Anderton stated: "The end of the Cold War has increased the relative importance of economic causes and consequences of arms transfers. Unfortunately, there is surprisingly little theoretical and empirical development of arms trade". 3 According to the author, the main cause for this knowledge gap lies in the "failure, to date, to develop explicit sets of formal relationships between dependent and independent variables", which Anderton primarily attributes to "a lack of trying". 4

Just over a quarter of a century later, this chapter aims to revisit Anderton's seminal research. More specifically, the question we ask in the title, 'What do we know?' refers to our interest in theoretical and empirical developments regarding explicit sets of relationships between dependent and independent variables in the international arms trade, over the past 25 years. To take stock of research findings to this effect, primarily, the literature review focuses on conjectures, refutations and/or confirmations instead of on "descriptive compilations of data, case studies

\footnotetext{
${ }^{1}$ Kempf 2016, pp. 4-29; Stohl and Grillot 2009, pp. 10-40; Voetelink 2017, p. 378.

${ }^{2}$ Kempf 2016, p. 30.

${ }^{3}$ Anderton 1995, p. 524.

${ }^{4}$ Anderton 1995, p. 535.
} 
and journalistic accounts". 5 However, to achieve an overarching picture on state-ofthe-art economics of arms exports, we have also included more descriptive findings in our review.

Within the scope of this volume, we will not redo Anderton's analysis fully. Instead, this chapter, as mentioned above, offers our initial findings regarding the progress made to fill the knowledge gap regarding why, how and to what extent economic motives and the international arms trade are interrelated.

The remaining part of this chapter is structured as follows. The next section outlines the research methodology, to be followed by the chapter's main body, entailing the results of the literature study. Next, these findings will be analysed, to be followed by some concluding remarks and an agenda for future research.

\subsection{Research Methodology}

Literature reviews require transparent processes, characterized by clear steps and considered decisions on the selection of papers. ${ }^{6}$ In this section, first, we will define this research's scope, and the selection methods and criteria we have applied. Last, this section will offer a synthesized overview, based on additional research (from 1995 onwards) on the explicit sets of relationships between dependent and independent variables in the international arms trade.

Before proceeding with the remaining part of this methodology section, first, we elaborate shortly on the five categories, generally distinguished in the international arms trade, of military and dual-use goods and services. ${ }^{7}$ These categories comprise weapons of mass destruction, major weapon systems, small arms and light weapons, dual-use goods, and services (e.g., training and maintenance). ${ }^{8}$ Each category raises specific managerial challenges and controversies, requiring different market structures and control mechanisms.

Although widespread consensus exists as to the control of proliferation of chemical, biological, radiological and nuclear weapons, this cannot be said about general controls regarding the sales of conventional weapons. With respect to conventional weapons, it is useful to distinguish major weapon systems from small arms and light weapons. Compared to major weapon systems, the market for light weapons is more difficult to control, partly because major weapon systems are supplied by an oligopoly, whereas light weapons are competitively supplied by large number of producers. Dual-use systems raise unique difficulties, such as the spread of militaryrelevant knowledge via civil trade transactions. Services are becoming increasingly important in the transfer of military-relevant knowledge and technology.

\footnotetext{
${ }^{5}$ Anderton 1995, p. 525.

${ }^{6}$ Kalkman 2020.

${ }^{7}$ Smith and Udis 2001, p. 82.

${ }^{8}$ Levine and Smith 1997, pp. 340-341; Smith and Garcia-Alonso 2006, p. 29; Smith and Udis 2001, p. 82 .
} 


\subsubsection{Scope}

Our literature review focuses on the ways in which economic motives and the international arms trade are (inter)related. The chapter's scope, therefore, remains limited to research that contributes to understanding the economic drivers prompting international trade of military and dual-use goods and services. Literature on international law and other adjacent domains, have not been included in the review. We do acknowledge these domains' important contributions to a broader area of expertise, as well as their attention to some economic parameters concerning the international arms trade. However, in general, these adjacent bodies of literature will not directly contribute to improved understanding of the theoretical and empirical developments regarding explicit sets of relationships between dependent and independent variables in the international arms trade over the past 25 years.

\subsubsection{Selection}

The literature review underpinning this research has been restricted to published and peer reviewed academic papers, in English. Books and book chapters have been used as supporting literature. Queries used in Google Scholar are "arms exports", "(international) arms trade", "economics of arms trade" and "economics of arms exports". These queries are chosen, based on relevance and coverage, as key words for papers regarding our actual research interests.

Table 2.1 provides an overview of our classification of the selected papers. For each category (i.e., weapons of mass destruction (WMD), major weapon systems (MWS), small arms and light weapons (SALW), dual-use technologies or goods (DUG), and (5) services (SERV)), papers are ordered by research type (theoretical or empirical) and methodology (analytical, descriptive, exploratory, testing). We added a sixth category, general (GEN), for research papers that discuss the market of military and dual-use goods and services in general -often analytical- terms.

As of yet, our dataset-in progress-consists of 30 papers (see Table 2.1). Two papers span more than one category (which is why the columns 'theoretical' and 'empirical' in Table 2.2 add up to 32 instead of 30). Berryman provides an analysis of both major weapon systems and weapons of mass destruction. ${ }^{9}$ Fuhrmann researches the relationship between both dual-use and weapons of mass destruction. ${ }^{10}$

Table 2.2 aims to provide insights into the most important contribution the papers add to literature. Looking at research into the differing categories of weapon systems, it turns out most studies are conducted into markets for major weapons systems

\footnotetext{
${ }^{9}$ Berryman 2000, p. 85.

${ }^{10}$ Fuhrmann 2009b, p. 7.
} 
Table 2.1 Selected papers on the economics of exporting arms

\begin{tabular}{|c|c|c|c|}
\hline Paper & Market & Research type & Methodology \\
\hline Akerman and Larsson Seim (2014) & MWS & Empirical & Exploratory \\
\hline Berryman (2000) & WMD/MWS & Empirical & Descriptive \\
\hline Blum (2019) & MWS & Theoretical & Testing \\
\hline Craft (2000) & MWS & Theoretical & Testing \\
\hline Dunne and Smith (2016) & MWS & Empirical & Descriptive \\
\hline Fuhrmann (2008) & DUG & Theoretical & Testing \\
\hline Fuhrmann (2009a) & DUG & Theoretical & Testing \\
\hline Fuhrmann (2009b) & WMD/DUG & Theoretical & Testing \\
\hline Fuhrmann and Tkach (2015) & WMD & Theoretical & Testing \\
\hline Garcia-Alonso and Levine (2007) & GEN & Theoretical & Analytical \\
\hline Golde and Tishler (2004) & GEN & Theoretical & Analytical \\
\hline Holtom and Bromley (2010) & GEN & Empirical & Descriptive \\
\hline Khanna and Chapman (2010) & MWS & Empirical & Exploratory \\
\hline Killicoat (2006) & SALW & Empirical & Testing \\
\hline Klare (1996) & MWS & Empirical & Descriptive \\
\hline Levine et al. (1998) & MWS & Empirical & Exploratory \\
\hline Levine and Smith (1995) & GEN & Theoretical & Analytical \\
\hline Levine and Smith (1997) & GEN & Theoretical & Analytical \\
\hline Levine and Smith (2000a) & GEN & Theoretical & Analytical \\
\hline Levine and Smith (2000b) & GEN & Theoretical & Analytical \\
\hline Martinez-Zarzoso and Johanssen (2019) & MWS & Theoretical & Testing \\
\hline Moore (2010) & MWS & Theoretical & Testing \\
\hline Pamp et al. (2018) & MWS & Theoretical & Testing \\
\hline Pamp and Thurner (2017) & MWS & Theoretical & Testing \\
\hline Sandler (2000) & GEN & Theoretical & Descriptive \\
\hline Seyoum (2017) & DUG & Theoretical & Exploratory \\
\hline Smith and Tasiran (2005) & MWS & Empirical & Exploratory \\
\hline Smith and Udis (2001) & GEN & Theoretical & Descriptive \\
\hline Thurner et al. (2019) & MWS & Theoretical & Testing \\
\hline Thurner et al. (2020) & MWS & Theoretical & Testing \\
\hline
\end{tabular}

Source van Lieshout and Beeres 2021

(Row MWS; $\mathrm{n}=15) .{ }^{11}$ As to studies on dual-use goods (Row DUG; $\mathrm{n}=4$ ); ${ }^{12}$

\footnotetext{
11 Akerman and Larsson Seim 2014; Berryman 2000; Blum 2019; Craft 2000; Dunne and Smith 2016; Khanna and Chapman 2010; Klare 1996; Levine et al. 1998; Martinez-Zarzoso and Johanssen 2019; Moore 2010; Pamp et al. 2018; Pamp and Turner 2017; Smith and Tasiran 2005; Thurner et al. 2019, 2020.

${ }^{12}$ Fuhrmann 2008, 2009a, b; Seyoum 2017.
} 
Table 2.2 Papers on the economics of exporting arms

\begin{tabular}{l|l|l|l|l|l|l}
\hline Categories & Theoretical & Empirical & Analytical & Descriptive & Exploratory & Testing \\
\hline WMD & 2 & 1 & - & 1 & - & 2 \\
\hline MWS & 8 & 7 & - & 3 & 4 & 8 \\
\hline SALW & 1 & - & - & - & - & 1 \\
\hline DUG & 4 & - & - & - & 1 & 3 \\
\hline SERV & - & - & - & - & - & - \\
\hline GEN & 8 & 1 & 6 & 3 & - & - \\
\hline N & 23 & 9 & 6 & 7 & 5 & 14 \\
\hline
\end{tabular}

Source van Lieshout and Beeres 2021

weapon of mass destruction equals 4 (Row WMD; $\mathrm{n}=3$ ). ${ }^{13}$ Last, and least popular, apparently, are studies on small arms and light weapons (Row SALW; $\mathrm{n}=1$ ). ${ }^{14}$ Most theoretical papers test developed theories using empirical data collections. Two exceptions are to be made. Regarding the dual-use category, Seyoum develops hypotheses regarding export control that could be tested (for this reason we consider this study both theoretical and exploratory). Next, although all papers in the 'general' category are considered theoretical, they either develop analytical models $(n=6)^{15}$ or deliver a general perspective on the most important theoretical issues concerning arms trade and export control $(\mathrm{n}=3) .{ }^{16}$ Empirical papers are either descriptive or exploratory.

\subsubsection{Research Synthesis}

Our analysis of the collected papers reflects a growing academic interest in the economics of arms trade over the last decades. The earliest papers develop analytical models. Researchers look for variables and parameters, that according to them, are important to map the field empirically. Next, they engage in systematic empirical descriptive research by actually collecting variables and parameters to be followed by an empirical exploratory phase, during which hypotheses are developed. Last, hypotheses are tested during the theoretical testing phase, when it is studied whether the relationships between dependent and independent variables that have been formulated, actually do appear. Researchers focused on finding reasons, motives and explanations for decisions to buy or sell arms, per category (e.g., Killicoat on SALW). ${ }^{17}$

\footnotetext{
${ }^{13}$ Berryman 2000; Fuhrmann 2009b; Fuhrmann and Tkach 2015.

${ }^{14}$ Killicoat 2006.

${ }^{15}$ Garcia-Alonso and Levine 2007; Golde and Tishler 2004; Levine and Smith 1995, 1997, 2000a, b.

${ }^{16}$ Holtom and Bromley 2010; Sandler 2000; Smith and Udis 2001.

${ }^{17}$ Killicoat 2006.
} 
A majority of papers is built on quantitative analysis of a combination of datasets. Data on statistics per state and on procurement of arms are used for explanatory analysis throughout the years of relevant research. Few authors enrich quantitative projects with qualitative methods. ${ }^{18}$ Due to legal reporting requirements, data sets on national defence expenditures became available and turned out to be useful sources for further research (e.g., Pamp and Thurner). ${ }^{19}$ The availability of data resulted in a certain progress in gaining knowledge on arms exports, leading to the development of theoretical models, starting with a rather traditional supply and demand model, ${ }^{20}$ ending (for the time being) with network modelling. ${ }^{21}$

In the next section, we will illustrate both theoretical and empirical developments regarding explicit sets of relationships between dependent and independent variables in the international arms trade, over the past 25 years. In doing so, we will focus on four out of six categories of military and dual-use goods and services identified (i.e., weapons of mass destruction (WMD), major weapon systems (MWS), small arms and light weapons (SALW) and dual purpose goods (DUG)). As we have not been able to identify any academic papers on the category services (SERV), we have decided to exclude this category. The same applies to the category 'general' (GEN), as, from literature, it appears no hypotheses testing is being undertaken.

\subsection{Weapons of Mass Destruction}

This section discusses two papers and offers a brief conclusion.

\subsubsection{Spreading Temptation: Proliferation and Peaceful Nuclear Cooperation Agreements ${ }^{22}$}

This paper's main question is: To what extent does civilian nuclear assistance raise the risk of the proliferation of nuclear weapons? Answers are provided both by qualitative analysis - showing the effect of nuclear assistance on proliferation-as well as quantitative analysis - to explain and test this effect. The study's dependent variables are 'the initiation of a nuclear weapons program' and 'the acquisition of nuclear weapons of the state receiving nuclear assistance'. The 'aggregate number of nuclear cooperation agreements' between two states and 'security threats' are the most important explanatory variables. The 'aggregate number of nuclear cooperation agreements' is operationalized using different data sets, spanning the years

\footnotetext{
18 Fuhrmann 2009b.

19 Pamp and Thurner 2017.

${ }^{20}$ Levine et al. 1994.

21 Thurner et al. 2019, 2020.

${ }^{22}$ Fuhrmann 2009b.
} 
1945-2000. The main results are: (1) states receiving civilian nuclear assistance are more likely to start a nuclear weapons program than states that do not and (2) states receiving nuclear assistance are more likely to acquire nuclear weapons. If and when "countries generally want to limit the spread of nuclear weapons and if nuclear cooperation agreements lead to proliferation", based on these findings another question pops up: Why (for what reason) should civilian nuclear assistance be extended to countries, that cannot yet avail of such capacities? ${ }^{23}$

\subsubsection{Almost Nuclear: Introducing the Nuclear Latency Dataset $^{24}$}

In their paper, Fuhrmann and Tkach investigate the relationship between the capacity of building nuclear weapons (i.e., nuclear latency) and international conflict, using a dataset on nuclear latency that is introduced concurrently. The paper's main question is: 'Does having nuclear latency reduce the likelihood of being targeted in an armed conflict'? The dependent variable is 'initiation of militarized conflict between states'. The authors introduce four independent variables, 'target country has nuclear latency'; 'challenging state has nuclear latency'; 'target country has an active nuclear bomb program' and, last, 'challenging state has an active bomb program'. Fuhrmann and Tkach find that possessing nuclear latency as a potential target reduces the risk of conflict. However, if and when challenging states hold nuclear latency, there will be no reduction of the risk of conflict. This study's main finding is that trade in (nuclear) enrichment and reprocessing facilities should be monitored, as merely being able to make nuclear bombs appears (at least) as powerful as actually possessing nuclear weapons. For within this category, trade does not exist.

\subsubsection{Research on Weapons of Mass Destruction: What Do We Know?}

The papers discussed above increase our knowledge on the issue of nuclear proliferation. Both the decision to provide civilian nuclear assistance and the decision to obtain latent nuclear capabilities appear essential steps in the proliferation process. Further investigation into the motives for countries to provide and to obtain nuclear capabilities is warranted.

\footnotetext{
${ }^{23}$ Fuhrmann 2009b, p. 41.

${ }^{24}$ Fuhrmann and Tkach 2015.
} 


\subsection{Major Weapon Systems}

As it turns out from our literature review, from 1995 onwards most studies have been conducted on the category of military goods and services. The following sections will discuss seven papers, offering a brief conclusion at the end.

\subsubsection{The Gravity of Arms ${ }^{25}$}

The main research question of this paper is: What are the determinants of international arms transfers? In answering this question, the authors show the impact of several economic, political and security factors on (1) the probability of trading arms and (2) the value of arms transfers. The SIPRI Arms Transfers Database, containing information on values of shipments between two parties, is used for quantitative analysis. Moreover, relevant sources are added to obtain data on economic and political factors. The main question is analysed by applying an economics based gravity model framework, augmented by political and security motives. Determinants of the 'probability of trading arms' and 'volume traded' are modelled and analysed. Results on the probability of arms transfers between two states as well as the value of such transfers, follow the theory of gravity (i.e., the probability increases whenever countries are closer to each other, whilst decreasing when there is more distance -both physically and politically). Economic factors (e.g., wealth) and security factors (e.g., the presence or absence of the threat of conflict) affect the value of arms transfers. However, most effects are quite small. The authors argue that the "end of the Cold War appears to have changed the impact of several political factors, especially those measuring the political and security factors". ${ }^{26}$ However, the authors also conclude that upon the fall of the Berlin Wall "it is crucial to consider political factors, such as the level of democracy or the political orientation, as explanatory factors of the arms trade". ${ }^{27}$

\subsubsection{Arming the Embargoed ${ }^{28}$}

Moore asks: Why do states continue to transfer arms to embargoed states? The dependent variables being 'the occurrence of a violation of an U.N. arms embargo' and 'the volume of an occurring violation'. Moore's analysis takes different explanatory variables into account, such as 'arms dependence of embargoed states', 'common policy interests' and variables such as 'military expenditure', 'total arms imports'

\footnotetext{
${ }^{25}$ Martinez-Zarzoso and Johannsen 2019.

${ }^{26}$ Martinez-Zarzoso and Johannsen 2019, p. 3.

${ }^{27}$ Martinez-Zarzoso and Johannsen 2019, p. 3.

${ }^{28}$ Moore 2010.
} 
and 'arms export dependence'. Results show that embargoes on arms transfers are not that effective as they are meant to be. Selling states violate arms embargoes mainly because of their own strategic interests. The volumes of arms exports to embargoed states are increasing whenever importing states sand arms exporting states share similar political interests. Regarding the dynamics of the international arms trade and exports, Moore shows that arms embargoes do not negatively influence arms exports. A weapons ban does not usually stop weapon sales.

\subsubsection{Arms Production, National Defence Spending and Arms Trade ${ }^{29}$}

The paper's main question is: How do national defence spending and arms transfers relate to sales of military goods? The dependent variable is 'total sales of arms and military services'. 'Total national spending on defence' and 'arms exports and imports' are added as explanatory variables. It turns out that defence spending has a positive effect on arms sales of the same country: a one per cent increase in defence spending results in a 1.2 per cent increase in arms sales. The export of arms generates a similar but however more modest effect on sales. Arms imports do not affect total arms sales of the importing country. Results show that importing weapons does not replace national arms production, but, rather, complements it. This paper's findings show how supply and demand for military goods and services are related. Confirmation is found in the relations between sales of arms and arms exports on one side and between sales and defence spending on the other. The finding that arms imports are complementary to homemade weapon systems, in our view, is the most important result of this research.

\subsubsection{Trading Arms and the Demand for Military Expenditure $^{30}$}

Pamp and Thurner investigate the influence of the international arms trade on domestic military spending. Using SIPRI data on major weapon systems from 1949 until 2013, the authors apply regression analysis to establish the effects of the levels of arms imports and arms exports as independent variables on the dependent variable military expenditures, controlling for democracy and wealth and size of population. Results show that military spending increases when arms imports increase. The same effect is found with control variables measuring military conflict; more conflicts induce more military spending. In democratic states, increases in arms exports result

\footnotetext{
${ }^{29}$ Blum 2019.

${ }^{30}$ Pamp and Thurner 2017.
} 
in decreased domestic military spending. The paper's main finding holds that "arms exports to allied countries could be used strategically to reduce the defence burden".

\subsubsection{Arm Your Friends and Save on Defence? ${ }^{31}$}

Elaborating on their former paper, Pamp, Dendorfer and Thurner proceed to further investigate the question: How do arms export decisions affect decisions about domestic military spending? To this end, the authors develop a formal model to explain suggested interactions or relations between both decisions. SIPRI data on arms trade and military expenditures are used in an extended model, derived from Levine, Sen and Smith. ${ }^{32}$ The dependent variable is 'military expenditures' and the main independent variable is 'arms exports'. An interaction dummy variable is included in the form of positive security externality. If and when arms exports generate such positive security externality and, moreover, two aligned democracies are involved, countries appear motivated to spend less on their domestic defence budgets. The paper's main finding is that arms exports between friends offer the exporting country an opportunity to decrease domestic defence expenditures, thus, selling leads to savings.

\subsubsection{Network Interdependencies and the Evolution of the International Arms Trade ${ }^{33}$}

This paper aims to clarify the structure of international networks in the field of exchange of defence technology, and, to this effect, the paper takes a network-oriented approach. The existence of any arms export relationship between two parties (yes/no) serves as dependent variable. Additional explanatory variables are wealth (GDP), gravity model variables (distance, trade restrictions), regime similarity, defence agreement and intra-state conflict and path dependency. Main findings include that, as opposed to what would randomly be expected, countries actually maintain less export and import relationships with other countries, in combination with a low rate of reciprocation (due the fact the number of countries outranks the number of arms suppliers). Because of dependencies on arms supplying companies or states, relationships tend to linger, the same applies to relations between states which are politically similar to each other. Alliance memberships, transactional costs and GDP of exporting and importing states have strong (positive) influences on the probability of arms transfers. In the imperfect arms market, international relationships are not restricted to dyadic relations; two states trading arms with the same third party tend

\footnotetext{
${ }^{31}$ Pamp et al. 2018.

${ }^{32}$ Levine et al. 1994.

33 Thurner et al. 2019, 2020.
} 
to have a similar relationship with one another. Besides the corroborating these findings -in previous studies on network modelling, this paper contributes knowledge on more complex relations between arms exporting- and importing countries. Two states selling arms to the same friend, appear highly probable to also trade weapons with each other. The international arms trade should therefore be understood as a network, instead of one-to-one relations. This fundamentally adds to knowledge on the structure of the international arms market.

\subsubsection{Research into Major Weapon Systems: What Do We Know?}

We conclude international trade in major weapon systems is influenced by multiple factors. Based on the papers discussed above, from 1995 onwards the importance of economic motives underlying major weapon systems transfers has been increasing. Moreover, after the fall of the Berlin Wall, strategic and political factors in this segment of the international arms trade have remained influential. Also, in research, relations between national defence spending and the transfer of major weapon systems are increasingly gaining attention. Partly this may be due to the fact that the SIPRI database accommodates researchers with data at a low cost. However, hypotheses testing on strategic benefits to be gained (e.g., reduction of national defence burdens) by exporting major weapon systems remain understudied. To us, studies geared towards "describing, explaining and even predicting the structure of the international arms trade network" regarding major weapon systems is an interesting development, that should, in future, include export control laws and regulations, particularly ITAR.

\subsection{Small Arms and Light Weapons}

This section discusses one paper.

\subsubsection{Weaponomics, the Economics of Small Arms ${ }^{34}$}

The main question put forward in this paper is: What are the key determinants of assault rifle prices? To this end, over four time periods, the author has collected prices and related characteristics of the AK-47 assault rifle, and proceeded to test four factors, potentially determining the rifle's price, 'income'; 'motivation to buy'; 'regulation' and 'supply costs'. Based on this data, Killicoat constructs a weaponprice determinants model. Out of the four factors mentioned above, regulation and

\footnotetext{
${ }^{34}$ Killicoat 2006.
} 
supply costs are the two significant factors determining the price of the AK-47. Two variables on the demand side, showing some evidence in affecting prices of SALW, are increasing income and government effectiveness. Based on the results Killicoat provides additional insight into the determinants of the price of the AK-47; the rifle most bought and used all over the world.

\subsubsection{Research into Small Arms and Light Weapons: What Do We Know?}

Besides finding that, as yet, theoretical research and testing on SALW remains scarce, we conclude that studies in this field provide determinants on prices of assault rifles. It appears interesting to conduct similar studies, applying additional determinants also, and, extending these investigations to include other weapon systems -and categoriesas well.

\subsection{Dual-Use Goods}

In this section we discuss two papers.

\subsubsection{Exporting Weapons of Mass Destruction? ${ }^{35}$}

This paper sets out to find the determinants for dual-use trade in the post-Cold War era. Since data on the trade of dual-use goods itself are not available, the quantitative analysis is based on a data-set containing export licenses from the US to more than one hundred countries. The dependent variable is 'the volume of dual-use exports', which is operationalized as (1) the quantity of approved export licenses and (2) the total value of those licensed exports, in US dollars. Multiple independent variables (democracy, alliance sharing), indicator variables (military conflict, likelihood of conflict, states' pursuit of the acquisition of nuclear weapons) are selected. Effects of WMD acquisition and -pursuit on the trade of dual-use goods are tested by using two interaction variables (does a country own WMD and does a country pursue WMD). Main findings are that democracies received more dual-use exports than non-democratic states and dual-use goods are sold to countries that do not face security threats.

\footnotetext{
${ }^{35}$ Fuhrmann 2008.
} 


\subsubsection{Taking a Walk on the Supply Side: The Determinants of Civil Nuclear Cooperation ${ }^{36}$}

This paper asks: 'Why and when do states transfer nuclear technology, materials and knowledge to other states, for peaceful purposes'? To address this question the paper provides a quantitative analysis using a database on nuclear production capabilities and a self-compiled data set with agreements on civilian nuclear cooperation, nuclear suppliers and potential recipients for all agreements, over the period 1950-2000. The dependent variable in the analysis is 'the probability of peaceful nuclear assistance'. Independent variables are 'shared enemies', 'superpower enemies', 'military alliances', 'joint democracy' and 'militarized conflict'. Control variables are 'economic variables' (i.e., GDP, distance), 'nuclear proliferation' and 'contagion' (i.e., whether or not a neighbouring state receives nuclear aid). From the analysis it appears that three independent variables hold negative effects on the probability of peaceful nuclear assistance, i.e., conflict, distance and having signed a non-proliferation treaty. All other independent variables hold significant positive effects, except the variable on shared enemy. The paper's major finding is that the market for nuclear weapons, as measured by the indicator civilian nuclear assistance, is determined by strategic interests of states, able to supply nuclear goods and services. Most evident, the paper finds that states offer nuclear assistance to render their allies, enemies of their enemies, alliances and other democracies stronger.

\subsubsection{Research into Dual-Use Goods: What Do We Know?}

To date, theoretical research and testing on dual-use goods remains scarce. More studies into the determinants of prices and volumes of dual-use goods and services seem required, especially regarding the demands and requirements posed by export control laws and regulations, to this end. Seyoum's paper offers an interesting, explorative theoretical framework to do just that. ${ }^{37}$

\subsection{Analysis}

Taking an economic perspective, and underpinned by a literature review, this chapter investigates theoretical and empirical developments regarding explicit sets of relationships between dependent and independent variables in the international arms trade over the past 25 years. All in all, we find that from 1995 onwards, relevant studies have been conducted on the international arms trade. However, although

\footnotetext{
${ }^{36}$ Fuhrmann 2009a, b.

${ }^{37}$ Seyoum 2017.
} 
having outgrown its cradle, this particular research domain is still in the process of growing up and is in need of connecting with relevant and proven insights from neighbouring economic fields. The gravity model, for instance, featuring prominently international economic trade literature, is only recently being applied to studies on the international arms trade. ${ }^{38}$

A number of papers put forward rather generic hypotheses, which were statistically tested using 'free' databases, assembled by SIPRI or the researchers themselves. Although from Chap. 7 it becomes clear that far more databases are available, these are not generally being used. One reason may be that the use of these databases involves higher costs.

In addition, we have not found any research offering hard information on both price and quantity, simultaneously, although Killicoat's study comes close. Soft data are more commonly available (e.g., the number of licenses or probability data on the amount of transfers). As a consequence, our research tools are mainly limited to indicators or proxies. Compounding this lack of hard data, numbers and prices of major weapon systems are considered 'security information'. Although the categories small arms and light weapons and dual-use goods and services are subjected to less strict regulations, in both latter categories far less research is being conducted. Moreover, little attention to developments in the transfer of individual weapon systems is noticeable, again excepting Killicoat's study.

Finally, we find export control laws and regulations to be virtually absent in the economics-based theoretical and empirical development of arms trade, despite its major influence on the evolution of the structure of international defence technology frameworks. To us, it appears indicated to include this factor in future economic research on explicit sets of relationships between dependent and independent variables in the international arms trade.

\subsection{Conclusion: An Agenda for Research}

Based on our findings, this final section focuses on four interconnected research gaps and recommendations in the domain of the economics of the international arms trade.

From our literature review, it appears that from 1995 onwards, the main research effort has been geared towards the categories general and major weapon systems. Consequentially, characteristic methods and tools in research on the market of military and dual-use goods and services remain limited to modelling in general, often analytical terms and statistics. No distinctions are being made regarding individual weapon systems nor the quality thereof. We therefore recommend the conducting of research on the dynamics and determinants of prices and volumes in relation to the quality of individual weapon systems in the categories major weapon systems and small arms and light weapons.

38 Akerman and Larsson Seim 2014; Martinez-Zarzoso and Johanssen 2019. 
Second, it appears only minor research attention is paid to the category of dual-use goods, whilst there appears no academic interest to investigate the category services. As far as dual-use goods are concerned, this is striking, especially, given the fact that, from the perspective of (inter)national law and regulatory frameworks, dualuse goods are meticulously identified and listed. Although the category services is distinguished in literature, relevant journal papers could not be retrieved. Perhaps services should not be dealt with as a separate category, but, instead, be integrated as an element into the remaining categories.

Third, we recommend including the impact of arms export control laws and regulatory frameworks in economic based research, as these bodies appear to influence decision making in the international arms trade. A related question addresses what these ensuing effects on the international arms trade may be.

Last, we are convinced research on the economics of the international arms trade will be bolstered by designing a research programme, comparable to the defence economic programme devised for country studies in the journal Defence and Peace Economics.

\section{References}

Akerman A, Larsson Seim A (2014) The global arms trade network 1950-2007. Journal of Comparative Economics 42: 535-551

Anderton CH (1995) Economics of arms trade. In: Hartley K, Sandler T (eds) Handbook of defense economics, volume 1. Elsevier, Amsterdam, pp 524-561

Berryman J (2000) Russia and the illicit arms trade. Crime, Law and Social Change 33:85-104

Blum J (2019) Arms production, national defense spending and arms trade: examining supply and demand. European Journal of Political Economy 60. https://doi.org/10.1016/j.ejpoleco.2019. 101814

Craft CB (2000) An analysis of the Washington naval agreements and the economic provisions of arms control theory. Defence and Peace Economics 11:127-148

Dunne J, Smith R (2016) The evolution of concentration in the arms market. The Economics of Peace and Security Journal 11:12-17

Fuhrmann M (2008) Exporting mass destruction? The determinants of dual-use trade. Journal of Peace Research 45:633-652

Fuhrmann M (2009a) Taking a walk on the supply side. Journal of Conflict Resolution 53: 181-208

Fuhrmann M (2009b) Spreading temptation: proliferation and peaceful nuclear cooperation agreements. International Security 34:7-41

Fuhrmann M, Tkach B (2015) Almost nuclear: introducing the nuclear latency dataset. Conflict Management and Peace Science 32:443-461

Garcia-Alonso M, Levine P (2007) Arms trade and arms races: a strategic analysis. In: Sandler T, Hartley K (eds) Handbook of defense economics: defense in a globalized world, volume 2. Elsevier, Amsterdam, pp 941-972

Golde S, Tishler A (2004) Security needs, arms exports, and the structure of the defense industry. Journal of Conflict Resolution 48:672-698

Holtom P, Bromley M (2010) The international arms trade: difficult to define, measure and control. Arms Control Today 40:8-14

Kalkman JP (2020) Frontex: A literature review. International Migration. https://doi.org/10.1111/ imig. 12729 
Kempf JD (2016) Making A Killing: A Study of the Trade and Production of Arms. Bard College. https://digitalcommons.bard.edu/senproj_s2016/286

Khanna N, Chapman D (2010) Guns and Oil: An Analysis of Conventional Weapons Trade in the Post-Cold War Era. Economic Inquiry 48: 434-459

Killicoat P (2006) Weaponomics: The Economics of Small Arms. CSAE (University of Oxford). https://www.csae.ox.ac.uk/materials/papers/2006-13text.pdf Accessed 23 February 2021

Klare M (1996) The arms trade in the 1990s: changing patterns, rising dangers. Third World Quarterly 17:857-874

Levine P, Mouzakis, F, Smith R (1998) Prices and quantities in the arms trade. Defence and Peace Economics 9:223-236

Levine P, Sen S, Smith R (1994) A model of the international arms market. Defence and Peace Economics 5: 1-18

Levine P, Smith R (1995) The arms trade and arms control. The Economic Journal 105:471-484

Levine P, Smith R (1997) The arms trade. Economic Policy 12:336-370

Levine P, Smith R (2000a) Arms export controls and proliferation. Journal of Conflict Resolution 44:885-895

Levine P, Smith R (2000b) The arms trade game: from laissez-faire to a common defence policy. Oxford Economic Papers 52:357-380

Martinez-Zarzoso I, Johannsen F (2019) The gravity of arms. Defence and Peace Economics 30: $2-26$

Moore M (2010) Arming the embargoed: A supply-side understanding of arms embargo violations. Journal of Conflict Resolution 54:593-615

Pamp O, Dendorfer F, Thurner P (2018) Arm your friends and save on defense? The impact of arms exports on military expenditures. Public Choice 177:165-187

Pamp O, Thurner P (2017) Trading arms and the demand for military expenditures: empirical explorations using new SIPRI-data. Defence and Peace Economics 28:457-472

Sandler T (2000) Arms trade, arms control, and security: Collective action issues. Defence and Peace Economics 11:533-548

Seyoum B (2017) National Security Export Control Regimes: Determinants and Effects on International Business. Thunderbird International Business Review 59: 693-708

Smith R, Garcia-Alonso M (2006) The economics of arms export controls. In: Joyner D (ed) Nonproliferation export controls: origins, challenges, and proposals for strengthening. Ashgate, Farnham, pp 25-29

Smith R, Tasiran A (2005) The demand for arms imports. Journal of Peace Research 42:167-181

Smith R, Udis B (2001) New challenges to arms export control: Whither Wassenaar? The Nonproliferation Review 8:81-92

Stohl R, Grillot S (2009) The international arms trade. Polity Press, Cambridge.

Thurner PW, Schmid CS, Cranmer SJ, Kauermann G (2019) Network interdependencies and the evolution of the international arms trade. Journal of Conflict Resolution 63:1736-1764

Thurner PW, Schmid CS, Cranmer SJ, Kauermann G (2020) Corrigendum to network interdependencies and the evolution of the international arms trade. Journal of Conflict Resolution 64:1548-1552

Voetelink JED (2017) Exportcontrolerecht. Een verkenning. Militaire Spectator 186:376-390

Jan van Lieshout is assistant professor of Defence Economics at the Faculty of Military Sciences, Netherlands Defence Academy. His research interests include economics of international arms trade, counter-threat finance, (marketing of) terrorism and economics in general. He published articles and chapters in peer-reviewed journals and books.

Robert Beeres holds a Ph.D. in administrative sciences from Radboud University Nijmegen, The Netherlands. Currently he is a professor of Defence Economics at the Faculty of Military Sciences, Netherlands Defence Academy. His research interests include economics of arms export controls, 
defence capabilities, performance management and burden sharing within the EU and NATO. He published numerous articles in peer-reviewed journals and books and co-edited a number of books.

Open Access This chapter is licensed under the terms of the Creative Commons Attribution 4.0 International License (http://creativecommons.org/licenses/by/4.0/), which permits use, sharing, adaptation, distribution and reproduction in any medium or format, as long as you give appropriate credit to the original author(s) and the source, provide a link to the Creative Commons license and indicate if changes were made.

The images or other third party material in this chapter are included in the chapter's Creative Commons license, unless indicated otherwise in a credit line to the material. If material is not included in the chapter's Creative Commons license and your intended use is not permitted by statutory regulation or exceeds the permitted use, you will need to obtain permission directly from the copyright holder.

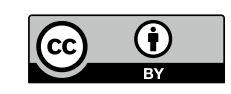

